\title{
ESTROGEN-LIKE PROPERTIES OF PERFLUOROOCTANOIC ACID AS REVEALED BY EXPRESSING HEPATIC ESTROGEN-RESPONSIVE GENES IN RARE MINNOWS (GOBIOCYPRIS RARUS)
}

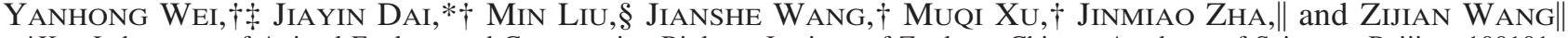 \\ $\dagger$ Key Laboratory of Animal Ecology and Conservation Biology, Institute of Zoology, Chinese Academy of Sciences, Beijing, 100101, \\ People's Republic of China \\ \$raduate School of the Chinese Academy of Sciences, Beijing, 100101, People’s Republic of China \\ $\S$ The Swire Institute of Marine Science, Department of Ecology and Biodiversity, University of Hong Kong, Pokfulam Road, \\ Hong Kong Special Administrative Region of the People's Republic of China \\ ||Research Center for Eco-Environmental Sciences, Chinese Academy of Sciences, Beijing, 100085, People's Republic of China
}

(Received 4 January 2007; Accepted 13 June 2007)

\begin{abstract}
Perfluorooctanoic acid (PFOA) is an important perfluorinated compound (PFC) with various applications and has been widely disseminated in the environment, wildlife, and humans. The present study investigated the effects of waterborne PFOA on the expression of hepatic estrogen-responsive genes, vitellogenin (VTG), and estrogen receptor $\beta$ (ER $\beta$ ) and on the gonadal development in a freshwater rare minnow (Gobiocypris rarus). The mRNA levels of VTG and ER $\beta$ were determined using reverse transcription polymerase chain reaction (RT-PCR) techniques, and VTG protein levels were identified using enzyme-linked immunosorbent assay. A significant increase of VTG expression in the livers of both mature males and females was observed after 14 and $28 \mathrm{~d}$ of exposure to 3,10, and $30 \mathrm{mg} / \mathrm{L}$ PFOA, indicating that PFOA could induce VTG synthesis. The expression of ER $\beta$ increased significantly in livers of both mature males and females after a 14-d exposure, although no difference was observed after a 28-d exposure. The development of oocytes in testes exposed to PFOA also provided evidence of estrogenic activity in males. The ovaries of PFOA-exposed females underwent degeneration, as reported in other fish species exposed to environmental estrogens. This preliminary study indicates that PFOA can disturb the activity of estrogen in mature male rare minnows by inducing hepatic estrogen-responsive genes, VTG and ER $\beta$, and barrier female reproduction.
\end{abstract}

Keywords-Perfluorooctanoic acid Rare minnow Estrogen-responsive gene Gonad Endocrine disruptors

\section{INTRODUCTION}

The commercial use of perfluorinated compounds (PFCs) for many applications for several decades has resulted in a broad distribution of stable precursors/metabolites in animals from terrestrial and aquatic environments [1-6]. Despite the widespread use of these compounds, relatively little is known of their fate and effects on animals [7,8]. Evidence that PFCs may disturb the endocrine system is increasing and deserves further investigation.

Perfluorooctanoic acid (PFOA) is a remarkably stable compound that does not undergo photolysis, hydrolysis, or biodegradation. It has been shown to produce hepatomegaly, induce hepatic peroxisomes, increase $\beta$-oxidation, and alter endocrine function in rodents [9-12]. In teleosts, circulating sex steroid levels in a freshwater species, fathead minnow ( $\mathrm{Pi}$ mephales promelas), can be affected significantly by exposure to fluorinated chemicals $[13,14]$. However, it is still unknown how the PFOA affected endocrine system and reproduction in teleosts.

Natural estrogens such as $17 \beta$-estradiol (E2) regulate the estrogen-responsive genes by binding to specific estrogen receptors (ER), which include two major isoforms (ER $\alpha$ and ER $\beta$ ) in teleosts. Then the estrogen-ER complex interacts with estrogen-responsive elements (EREs) of the target promoter genes and activates the transcription of estrogen-regulated

* To whom correspondence may be addressed (daijy@ioz.ac.cn). Published on the Web 6/22/2007. genes $[15,16]$. Among the estrogen-responsive genes, vitellogenin (VTG), precursor of egg yolk proteins, is synthesized in the liver of female teleosts in response to endogenous estrogens, transported to the ovary through the blood stream, and incorporated into the vitellogenic stage oocytes [17]. A high level of plasma and/or hepatic VTG is observed in mature females, whereas VTG levels in males and sexually immature individuals are relatively low or even undetectable. It is known to date that a number of environmental estrogens, such as alkylphenolic pesticides, can induce VTG synthesis in males. A significant increase of VTG in the plasma of a male therefore is considered as a sensitive biomarker of exposure to an estrogenic chemical [18].

In the present study, the freshwater teleost rare minnow (Gobiocypris rarus), a gonochoristic species, has many attractive features that make it a suitable organism in aquatic toxicity tests, including sensitivity to chemicals, small size, wide temperature range, ease of laboratory culture, and short embryonic development period $[19,20]$. The objective of the present study was to evaluate the in vivo effects of waterborne PFOA on mature male and female rare minnows under continuous flow-through conditions. We examined hepatic VTG and ER $\beta$ gene expressions using polymerase chain reaction (PCR) techniques, and measured VTG levels using enzymelinked immunosorbent assays. In addition, histopathological changes in gonads were examined under a light microscope at the end of the experiment, which provided insights into the effects of PFOA on the reproductive health of this species. 


\section{MATERIALS AND METHODS}

\section{Chemicals}

Perfluorooctanoic acid (98\%) was purchased from Acros Organics (Geel, Belgium). A polyclonal antiserum (anti-VTG), raised in rabbits against carp, generously was provided by $\mathrm{Y}$. $\mathrm{Xu}$ of the Institute of Hydrobiology, Chinese Academy of Sciences (Wuhan, People's Republic of China). Anti-rabbit immunoglobulin $\mathrm{G}$ conjugated with horseradish peroxidase was purchased from Promega (Madison, WI, USA).

\section{Fish and exposure experiments}

Two hundred and forty mature male and female rare minnows (about 9 months old with body wt of $1.4 \pm 0.4 \mathrm{~g}$ and total length of $47.7 \pm 3.6 \mathrm{~mm}$ ) were obtained from a laboratory hatchery and randomly assigned to eight 20-L glass tanks (30 individuals per tank). Fish were supplied with dechlorinated tap water under continuous flow-through conditions at $25 \pm$ $2{ }^{\circ} \mathrm{C}$ and a photoperiod of $16: 8$-h light:dark. During the $28-\mathrm{d}$ exposure period, fish were fed a commercial granular food (Tetra, Melle, Germany) at a daily rate of $0.1 \%$ body weight. Waste and uneaten food were removed daily. After a one-week acclimation period, 30 randomly selected male and 30 female rare minnows (gender determined by observing the shape of the abdomen and the distance between the abdomen fin and the stern fin) were assigned to one of the four treatments: PFOA exposure at $0,3,10$, or $30 \mathrm{mg} / \mathrm{L}$. Each treatment was in duplicate tanks. These concentrations were selected based on the literature [13]. The flow rate of the test solution was $8 \mathrm{~L} / \mathrm{h}$, and actual PFOA concentrations in the tanks were not verified by chemical analysis. During the exposure period, there were separate inputs for water and PFOA and the mixer helped mix PFOA and water before flowing into the tanks. The concentration of mixed solution flowing out from the mixer were kept at 3,10 , or $30 \mathrm{mg} / \mathrm{L}$ PFOA by adjusting the input flow rate of concentrated PFOA and water, respectively. After 14- and 28-d exposure periods, fish were anesthetized on ice, and liver samples were taken and immediately frozen in liquid nitrogen and stored at $-80^{\circ} \mathrm{C}$ until analyzed.

\section{Gonadal histology}

To investigate the histopathological changes in PFOA-exposed rare minnow gonads, ten males and ten females were collected from each treatment at the end of the experiment. For each fish, gonadal tissue was excised from the middle portion of one of the two lobes and fixed in $10 \%$ formalin. Tissues were dehydrated in ethanol, embedded in paraffin wax, sectioned transversely at 4 to $5 \mu \mathrm{m}$, mounted on slides, and stained with haematoxylin and eosin. Fish sexes and their maturation were determined on the basis of the gonadal structure and the degree of egg and sperm cell development, respectively [21].

\section{RNA extraction, gene expression quantification}

Total RNA and first strand complementary DNA (cDNA) synthesis were performed as described in the manufacturers' protocol. Briefly, for each individual analyzed, total RNA was extracted from $20 \mathrm{mg}$ of liver tissue using RNeasy Mini Kit (Qiagen, Hilden, Germany) and treated with RNase-free DNase I (Qiagen) to remove any remaining genomic DNA. The approximately $1 \mu \mathrm{g}$ of total RNA from each sample was reverse transcribed using oligo $(\mathrm{dT})_{15}$ primer (Promega) and MMuLV (Moloney murine leukemia virus) reverse transcriptase
(New England Biolabs, MA, USA) at $42^{\circ} \mathrm{C}$ for $60 \mathrm{~min}$, followed by $95^{\circ} \mathrm{C}$ for $5 \mathrm{~min}$.

The variations in VTG messenger RNA (mRNA) expression in male livers were evaluated by semiquantitative reverse transcription polymerase chain reaction (RT-PCR) using $\beta$ actin as an internal control. A cycle number within the exponential phase of the amplification curve was chosen for quantifying expression of the VTG gene. Vitellogenin primers were designed from the sequence in our cDNA library, available as GenBank (EE392488): 5'-ACAAAGTCACTGCCAA GGTT-3' (forward), 5'-AATGGTAAGAGTTCCGTCTG-3' (reverse). The product size was 364 base pairs (BP). The PCR was performed using PCR Master Mix (Promega) in $25 \mu \mathrm{l}$ containing $1 \times$ PCR buffer, $200 \mu \mathrm{M}$ deoxynucleotide triphosphates, and $0.5 \mu \mathrm{M}$ primer sets. Amplification of the VTG gene was carried out for 30 cycles with the following profile: Denaturation at $94^{\circ} \mathrm{C}$ for $5 \mathrm{~min}$, primer annealing at $60^{\circ} \mathrm{C}$ for $40 \mathrm{~s}$, primer extension at $72^{\circ} \mathrm{C}$ for $40 \mathrm{~s}$, and a final extension period at $72^{\circ} \mathrm{C}$ for $5 \mathrm{~min}$. Amplification of $\beta$-actin was carried out for 27 cycles using specific $\beta$-actin primers (forward: 5'-GCCGTGACCTGACTGACTAC-3', reverse: 5'-GCAAG ATTCCATACCCAAGA-3') with the following thermocycler profile: $40 \mathrm{~s}$ at $94^{\circ} \mathrm{C}$, primer annealing at $60^{\circ} \mathrm{C}$ for $40 \mathrm{~s}$, and primer extension at $72^{\circ} \mathrm{C}$ for $40 \mathrm{~s}$. The product size was 272 BP. The band densities of the resulting products were measured using Bandleader 3.0 Software (Magnitec, Tel Aviv, Israel). Each analysis was repeated three times and normalized against $\beta$-actin.

Quantitative RT-PCR was performed to evaluate VTG gene expression in female and ER $\beta$ in male and female livers using a QuantiTect Synergy Brands (SYBR) Green PCR kit (Qiagen) and Stratagene Mx3000P quantitative PCR (qPCR) system (Stratagene, La Jolla, CA, USA) in a $20-\mu 1$ total reaction volume including $10 \mu \mathrm{l}$ of $2 \times$ QuantiTect SYBR Green PCR master mix, $1 \mu \mathrm{l}$ cDNA template, and $0.5 \mu \mathrm{M}$ each of targetspecific primers. The primers of VTG and $\beta$-actin were the same as above. The primers of ER $\beta$ were designed based on the sequence from our rare minnow liver cDNA library (the accession number in GenBank is EE396691): 5'-TG TAGGGGATTCAAACCAGA-3' (forward); 5'-GAAGTAGG ACTAAACGCCAT-3' (reverse). The product size was 95 BP. Thermal cycling conditions were as follows: $95^{\circ} \mathrm{C}$ for $15 \mathrm{~min}$, 50 cycles of $94^{\circ} \mathrm{C}$ for $15 \mathrm{~s}, 60^{\circ} \mathrm{C}$ (VTG) or $58^{\circ} \mathrm{C}(\mathrm{ER} \beta)$ for $30 \mathrm{~s}$, and $72^{\circ} \mathrm{C}$ for $30 \mathrm{~s}$. After PCR, a melting curve analysis was performed to demonstrate the specificity of the PCR product, as displayed by a single peak (data not shown). Every sample was determined in triplicate. After verifying that the efficiencies of VTG, ER $\beta$, and $\beta$-actin amplifications were approximately equal, fold differences in VTG and ER $\beta$ expressions normalized by $\beta$-actin (compared to control) were calculated using the $2^{-\Delta \Delta \mathrm{Ct}}$ method [22].

\section{Measurement of hepatic VTG level}

For each individual analyzed, $30 \mathrm{mg}$ of liver tissue was sonicated in $500 \mu \mathrm{l}$ of ice-cold phosphate-buffered saline buffer ( $\mathrm{pH}$ 7.6) on ice for $5 \mathrm{~min}$ with a Digital Sonifier (Branson, Garner, NC, USA). Cellular debris was removed by centrifugation at $12,000 \mathrm{~g}$ for $20 \mathrm{~min}$ at $4^{\circ} \mathrm{C}$, and the supernatant was collected and stored at $-80^{\circ} \mathrm{C}$ until further analysis. Hepatic VTG levels were measured using the heterologous competitive enzyme-linked immunosorbent assay method as described by Zhong et al. [23] and Liao et al. [24], modified as follows. The 96 microwell plate was precoated with $750 \mathrm{ng} /$ 

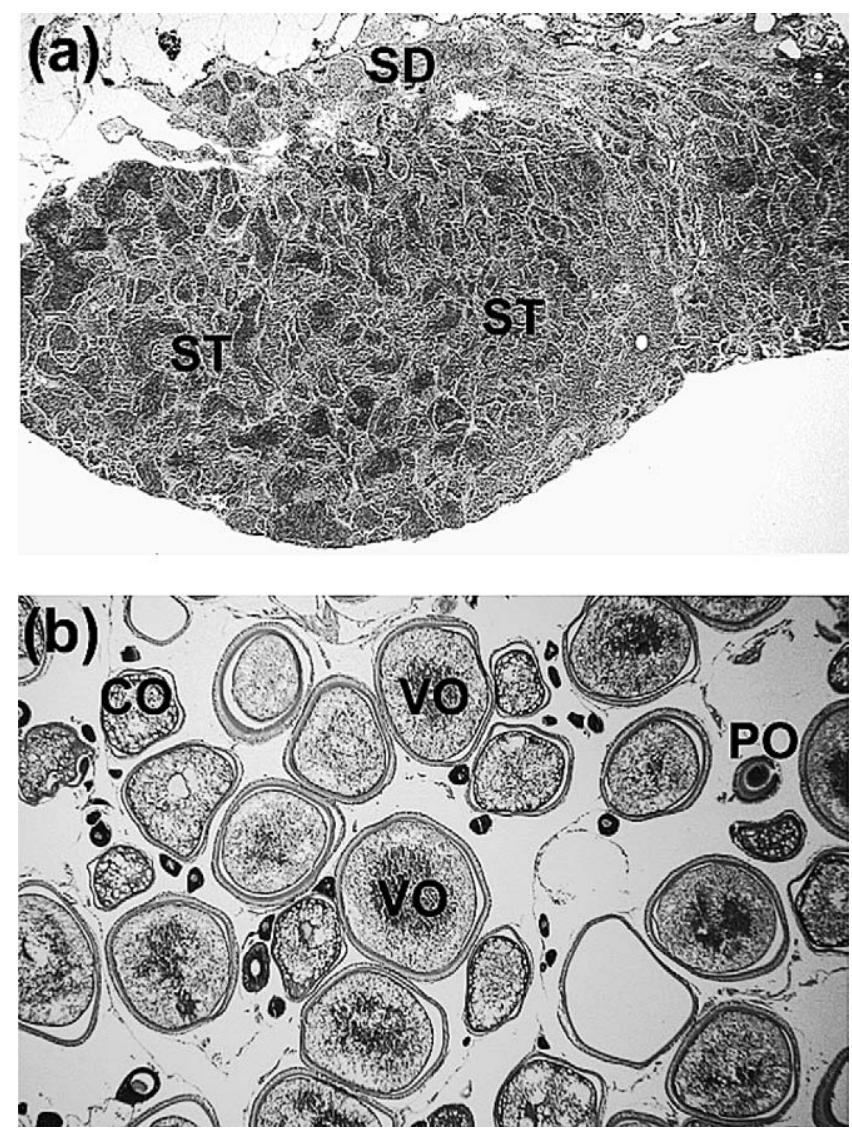

Fig. 1. Rare minnow gonads from control treatment. (a) Mature testis showing seminiferous tubules (ST) and sperm ducts (SD) filled with sperm $(\times 40)$. (b) Mature ovary showing various stages of oocyte development $(\times 40) . \mathrm{CO}=$ cortical-alveolus stage oocyte; $\mathrm{PO}=$ primary-growth stage oocyte; $\mathrm{VO}=$ vitellogenic stage oocyte.

$\mathrm{ml}$ purified carp VTG and incubated at $4^{\circ} \mathrm{C}$ overnight. Purified carp VTG was diluted with $0.05 \mathrm{M}$ Tris- $\mathrm{HCl}$ ( $\mathrm{pH} 7.5$ ) containing $0.05 \%$ Tween-20, $0.9 \% \mathrm{NaCl}$ (Tris-Tween buffered saline), and $3 \%$ bovine serum albumin in a twofold series from $2,000 \mathrm{ng} / \mathrm{ml}$ to $7.8 \mathrm{ng} / \mathrm{ml}$. Each standard or sample then was mixed $(1: 1, \mathrm{v} / \mathrm{v})$ with diluted anti-VTG $(1: 7,000)$ in a $96 \mathrm{mi}-$ crowell plate and incubated for $16 \mathrm{~h}$ at $4^{\circ} \mathrm{C}$. One hundred microliter of each preincubated standard dilution or sample was dispensed in triplicate into the coated plate, followed by incubation for $1 \mathrm{~h}$ at $32^{\circ} \mathrm{C}$, after which the plate was washed four times with Tris-Tween buffered saline. One hundred microliter of a second antibody, anti-rabbit immunoglobulin $\mathrm{G}$ conjugated with horseradish peroxidase (prepared at a final dilution of 1:2,500), was added to each well. After $1 \mathrm{~h}$ at $32^{\circ} \mathrm{C}$, the second antibody was removed and the plate was washed five times. Citrate buffer of $0.1 \mathrm{M}(\mathrm{pH} 5.0)$ containing $0.4 \mathrm{mg} /$ $\mathrm{ml}$ of $o$-phenylenediamine (Ameresco, Solon, OH, USA) and $0.15 \%(\mathrm{v} / \mathrm{v})$ hydrogen peroxide was added $(100 \mu \mathrm{l} / \mathrm{well})$. The plate was agitated gently and incubated at room temperature for $15 \mathrm{~min}$. The optical density was measured at $492 \mathrm{~nm}$ with a microtiter plate reader. The concentration of VTG in liver was normalized to protein mass of the corresponding sample and expressed in $n g / \mu g$ protein. Protein concentrations were measured by the Bradford method [25] using bovine serum albumin as a standard.

\section{Statistical analysis}

All values are expressed as mean \pm standard deviation. The statistical program SPSS ${ }^{\circledR}$ (Ver. 13.0, Chicago, IL, USA) was

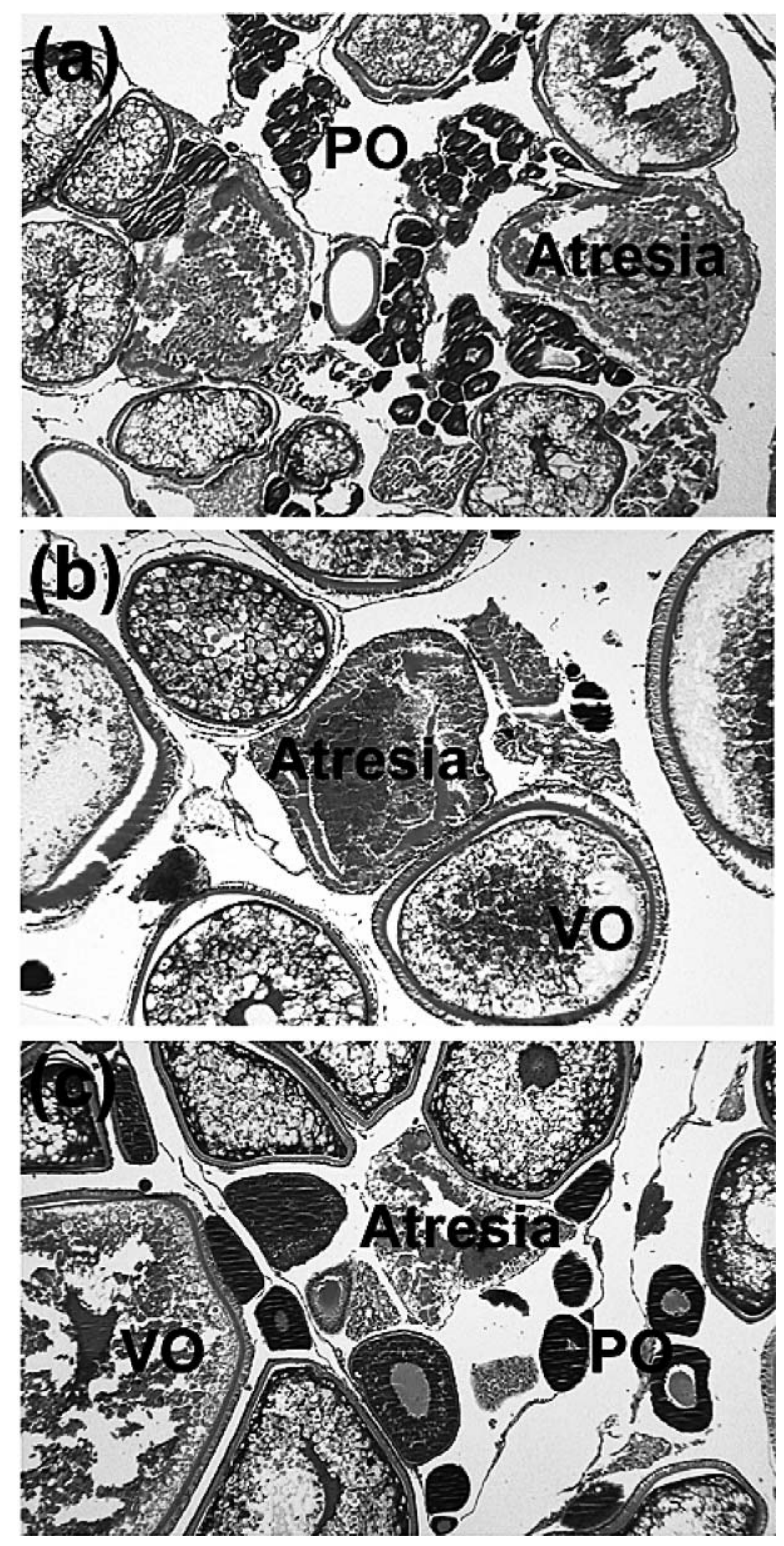

Fig. 2. Ovaries of mature female rare minnows exposed to perfluorooctanoic acid (PFOA) for $28 \mathrm{~d}$, showing the degeneration of vitellogenic stage oocyte (atresia). (a) $3 \mathrm{mg} / \mathrm{L}$ PFOA $(\times 40)$. (b) 10 $\mathrm{mg} / \mathrm{L}$ PFOA $(\times 100)$. (c) $30 \mathrm{mg} / \mathrm{L}$ PFOA $(\times 100)$. PO = primarygrowth stage oocyte; $\mathrm{VO}=$ vitellogenic stage oocyte.

used to collect and analyze all data. One-way analysis of variance was used to determine statistical differences among the treatment groups and $p<0.05$ was considered as significant.

\section{RESULTS}

\section{Histopathology}

No rare minnows died within the 28-d exposure period. Males and females in the controls $(0 \mathrm{mg} / \mathrm{L}$ PFOA) were mature, with seminiferous tubules and sperm ducts filled with sperm in the testes and vitellogenic-stage oocytes dominant in the ovaries, respectively (Fig. 1a and b). No evidence of degeneration was found in either testes or ovaries.

Mature females exposed to 3, 10, and $30 \mathrm{mg} / \mathrm{L} \mathrm{PFOA} \mathrm{for}$ $28 \mathrm{~d}$ had degenerating vitellogenic-stage oocytes (atresia) in the ovaries (Fig. 2a-c). The testes of mature males exposed to $3 \mathrm{mg} / \mathrm{L}$ PFOA were similar to those of the control males, 

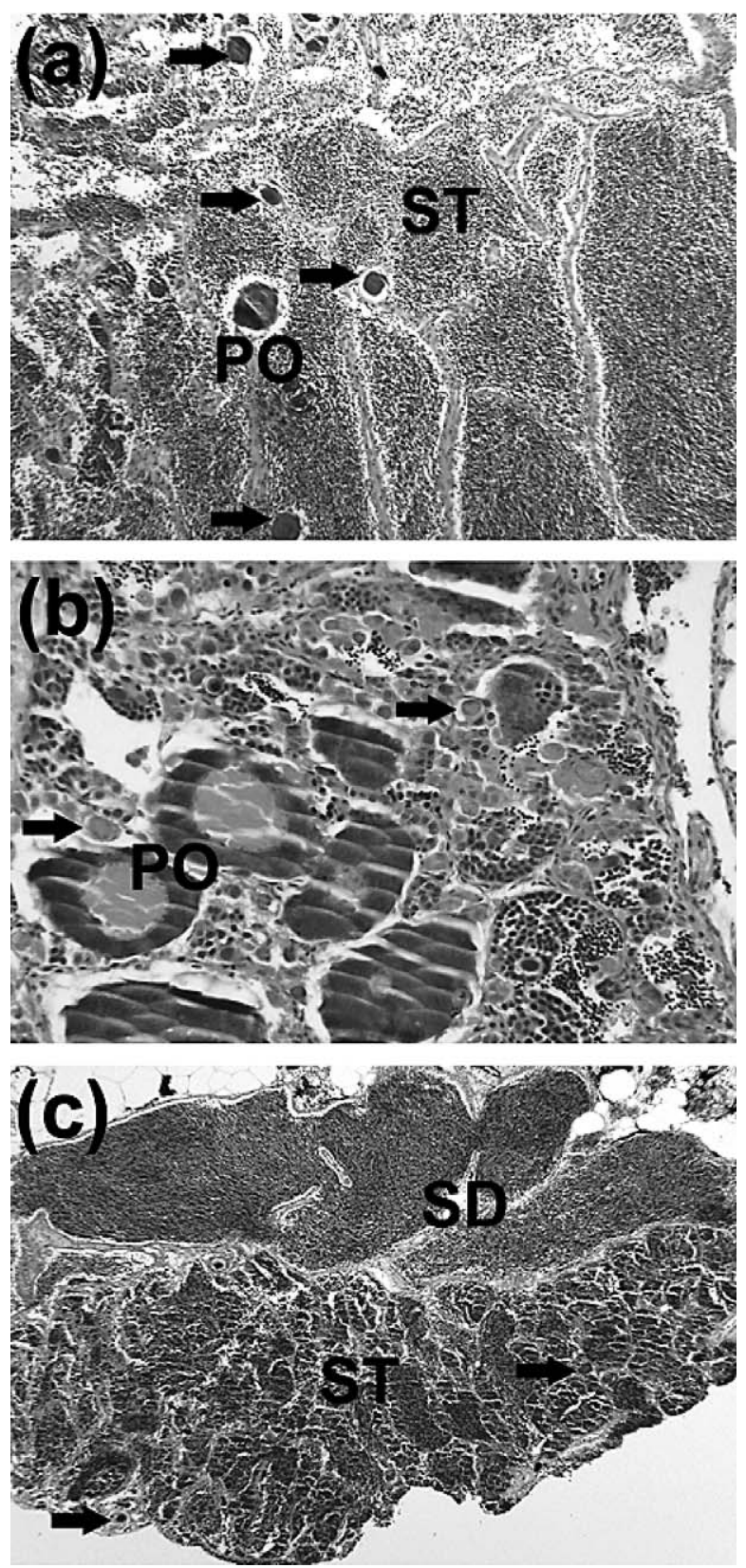

Fig. 3. Testes-ova of male rare minnows exposed to perfluorooctanoic acid (PFOA) for $28 \mathrm{~d}$. (a) $10 \mathrm{mg} / \mathrm{L}$ PFOA, showing seminiferous tubules (ST) filled with sperm and scattered primary-growth stage oocytes (PO and arrows) $(\times 200)$. (b) $10 \mathrm{mg} / \mathrm{L}$ PFOA, showing PO with earlier developing oocytes (arrows) $(\times 400)$. (c) $30 \mathrm{mg} / \mathrm{L}$ PFOA, showing seminiferous tubules (ST) and sperm ducts (SD) filled with sperm and scattered PO (arrows) $(\times 100)$.

and the seminiferous tubules were filled with large numbers of fertile sperm. In males exposed to $10 \mathrm{mg} / \mathrm{L}$ PFOA, primary growth-stage oocytes (previtellogenic oocytes) developed in some testes (3 out of 10 males; Fig. $3 a$ and b). Such testesova were not more advanced in males exposed to the highest concentration of PFOA (1 out of 10 males; Fig. 3c). The number of sperm and various stages of germ cells within the spermatogenic cycle in the 10 and $30 \mathrm{mg} / \mathrm{L} \mathrm{PFOA}$ treatments were lower than those in control males.

\section{Vitellogenin and ER $\mathrm{mRNA}$ levels in liver}

An agarose gel displayed VTG and $\beta$-actin products, generated in the RT-PCR reaction using total RNA isolated from the livers of males exposed to PFOA for 14 and 28 d (Fig. 4a and b). The VTG-specific cDNA band, which migrates at an effective predicted mass of $364 \mathrm{BP}$, was generated successfully with the VTG primer pair. The $\beta$-actin amplification products from liver total RNA have a mass of approximately 272 BP. The relative VTG expression levels of individual rare minnows from all four treatments were calculated after 14- and 28-d exposures (Fig. 4c and d). An analysis of variance was performed on the digital values of pixel density ratios from the agarose gels that yielded graphical data. Upregulation of hepatic VTG mRNA was observed in males exposed to 10 and $30 \mathrm{mg} / \mathrm{L}$ PFOA for $14 \mathrm{~d}$, but there was no significant difference in males exposed to $3 \mathrm{mg} / \mathrm{L}$ PFOA compared to the controls. All three levels of PFOA produced significant changes in VTG gene expression compared to the control group after the 28-d exposure.

Real-time quantitative PCR performed on female hepatic samples indicated that mRNA expression of VTG was significantly higher in all the treatment groups at 14 and $28 \mathrm{~d}$ than in the control treatments. In particular, there was a 37-fold increase in VTG expression in the $30-\mathrm{mg} / \mathrm{L}$ PFOA treatment group at $28 \mathrm{~d}$ (Fig. $4 \mathrm{~d}$ ).

After $14 \mathrm{~d}$ of exposure, the mRNA expression of ER $\beta$ in livers of all PFOA-exposed males and females exhibited the significant increase compared to the control males and females except males exposed to $3 \mathrm{mg} / \mathrm{L}$ PFOA ( $p=0.084$; Fig. 5a and $b$ ). The highest mRNA level of ER $\beta$ in males was in the 30-mg/L PFOA treatment, approximately twofold higher than that in the control males. The expression levels of ER $\beta$ mRNA in females exposed to PFOA were 1.3- to 1.5-fold higher than that in the control females. After $28 \mathrm{~d}$ of exposure, no difference in ER $\beta$ mRNA was observed in both males and females compared to the controls except the males exposed to 10 $\mathrm{mg} / \mathrm{L}$ PFOA. The mRNA of ER $\beta$ in this treatment was increased to 1.3-fold higher than that in the control males (Fig. $5 \mathrm{a}$ and $\mathrm{b})$.

\section{Hepatic vitellogenin concentration}

After $14 \mathrm{~d}$ of exposure to PFOA, hepatic VTG concentrations in males ranged from $0.58 \mathrm{ng} / \mu \mathrm{g}$ protein in the controls to $3.74 \mathrm{ng} / \mu \mathrm{g}$ protein in fish in the $30-\mathrm{mg} / \mathrm{L}$ PFOA exposure group (Fig. 6a). Hepatic VTG concentrations in males exposed to 10 and $30 \mathrm{mg} / \mathrm{L}$ PFOA after $14 \mathrm{~d}$ significantly increased (20 times higher) compared to the controls. After $28 \mathrm{~d}$ of exposure to PFOA, hepatic VTG concentrations in males ranged from $0.49 \mathrm{ng} / \mu \mathrm{g}$ protein in the controls to $1.88 \mathrm{ng} / \mu \mathrm{g}$ protein in the $10 \mathrm{mg} / \mathrm{L}$ PFOA exposure group (Fig. 6a). Hepatic VTG concentrations of males exposed to 3 and $10 \mathrm{mg} / \mathrm{L} \mathrm{PFOA}$ for $28 \mathrm{~d}$ significantly increased compared to the controls. However, hepatic VTG concentrations of males exposed to 30 $\mathrm{mg} / \mathrm{L}$ PFOA for $28 \mathrm{~d}$ decreased significantly compared to those exposed to 3 and $10 \mathrm{mg} / \mathrm{L}$ PFOA, which may be due to liver damage (data not shown). Hepatic VTG concentrations in males exposed to 10 and $30 \mathrm{mg} / \mathrm{L}$ PFOA decreased between 14 and 28 d (Fig. 6a). Liver VTG concentrations in females ranged from $1.17 \mathrm{ng} / \mu \mathrm{g}$ protein in the controls after the 14- $\mathrm{d}$ exposure to $4.75 \mathrm{ng} / \mu \mathrm{g}$ protein in the $10-\mathrm{mg} / \mathrm{L}$ PFOA exposure group after the 28-d exposure. Hepatic VTG concentrations in females exposed to PFOA for 14 and $28 \mathrm{~d}$ were increased significantly compared to the controls, except those exposed to $3 \mathrm{mg} / \mathrm{L}$ PFOA for $14 \mathrm{~d}$ (Fig. 6b). 
a

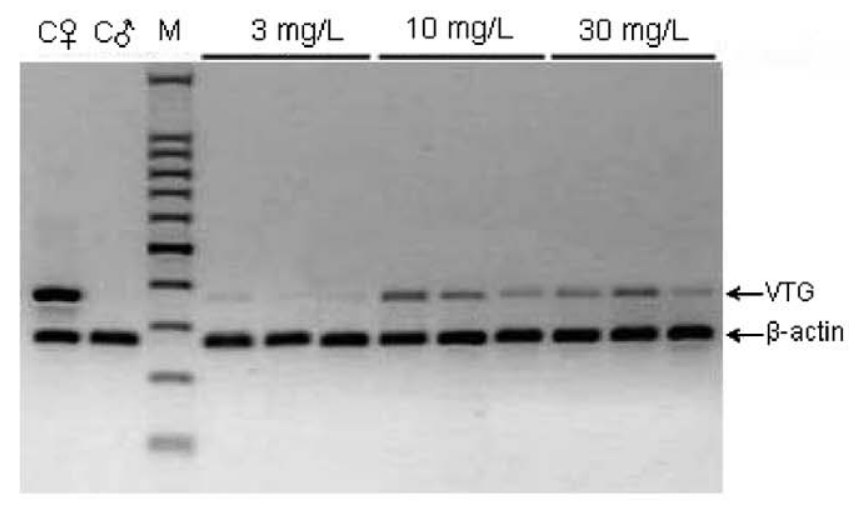

b

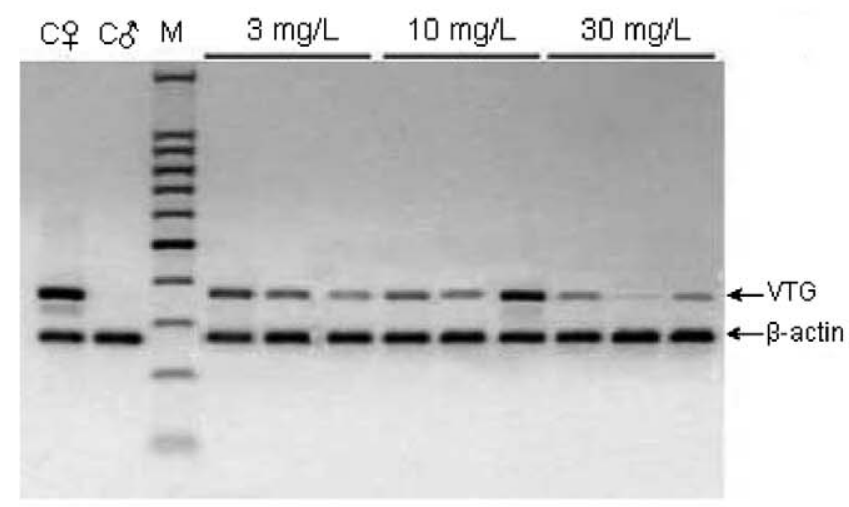

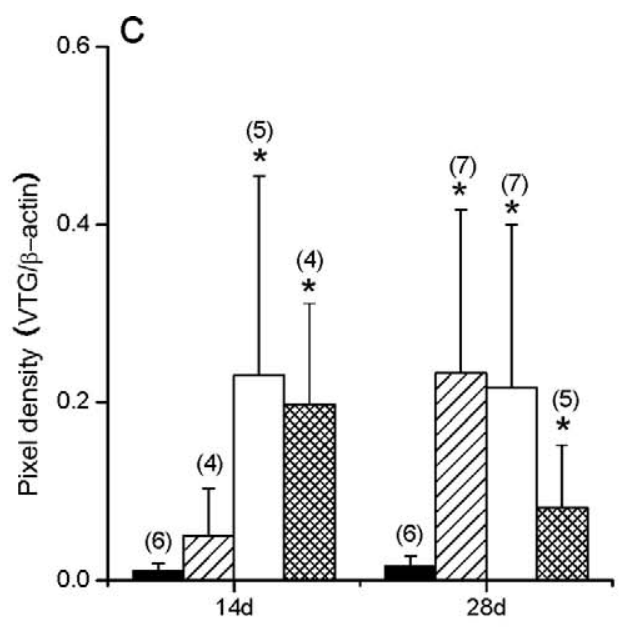

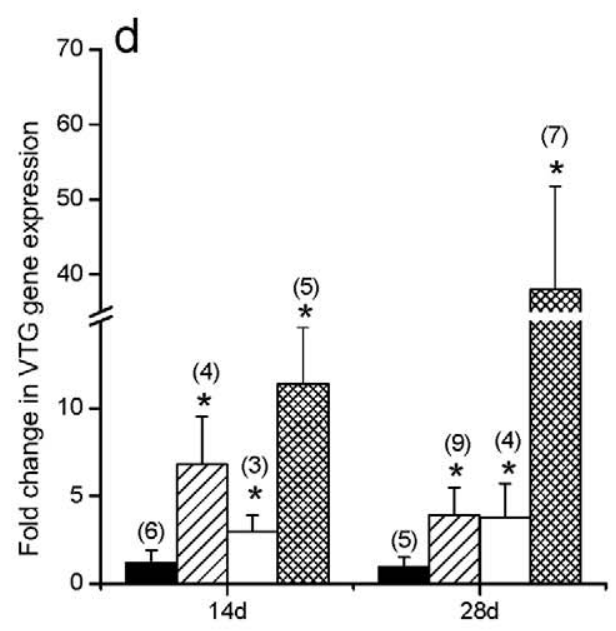

Control; $\mathbb{Z}_{3 \mathrm{mg} / \mathrm{L} ;} \square 10 \mathrm{mg} / \mathrm{L} ; \mathrm{x} 30 \mathrm{mg} / \mathrm{L}$

Fig. 4. (a and b) A representative agarose (1.8\%) gel image of amplification products of hepatic vitellogenin ([VTG], product size 364 base pairs) and $\beta$-actin internal standard (product size 272 base pairs) in individual male rare minnows exposed to perfluorooctanoic acid (PFOA). $\mathrm{C}+\stackrel{f}{=}$ female control; $\mathrm{C} \hat{0}=$ male control; $\mathrm{M}=1$ kilobase DNA marker; (a) exposed for $14 \mathrm{~d}$ and (b) exposed for $28 \mathrm{~d}$. (c) Graphical analysis of the relative band intensities (pixel densities) in males exposed to 3,10, and $30 \mathrm{mg} / \mathrm{L}$ PFOA; digitized pixel density values were calculated as VTG/ $\beta$-actin, expressed as means \pm standard deviation. Asterisks denote significant differences from the control at $p<0.05$. (d) Real-time quantitative polymerase chain reaction (PCR) analysis of hepatic VTG gene in females. Bars represent the fold change of exposed versus control, expressed as means \pm standard deviation. Asterisks denote significant differences from the control at $p<0.05$. (c and $\mathbf{d})$ Numbers of fish are given in parentheses.

\section{DISCUSSION}

In the present study, we demonstrated that PFOA, at concentrations well above those routinely reported in the environment, induces the synthesis of hepatic VTG and ER $\beta$ in both mature male and female rare minnows. The testes-ova observed in male rare minnows showed that PFOA exposure could disrupt the estrogen activity in males. In aquatic environment, PFOA levels in surface waters range from 0.011 to $67 \mu \mathrm{g} / \mathrm{L}$, and total perfluorinated surfactants downstream of spills can range up to $17 \mathrm{mg} / \mathrm{L}$ [26-28]. Although the PFOA concentrations in the present study were higher than those of surface waters, the results are useful in investigating mechanistic cause-and-effect relationships as well as predicting and evaluating the impact of spills.
Similar testes-ova also have been observed in several fish species exposed to endocrine disruptors. For example, testesova were detected in male rare minnows exposed to $17 \alpha-$ ethynylestradiol (EE2), 4-nonylphenol (NP), and diethylstilbestrol [23,29]. Gray and Metcalfe [30] reported that NP could induce testis-ova in male medaka (Oryzias latipes). Länge et al. [31] also reported that long-term exposure to EE2 resulted in the formation of testis-ova and the appearance of sex reversals in male fathead minnows. However, not all studies showed that fish exposed to endocrine disruptors developed testes-ova. For example, male fathead minnows exposed to E2 and EE2 for two to three weeks only exhibited a block of spermatogenesis and hyperplasia of sertoli cells [32], and male pearl dace (Margariscus margarita) exposed to EE2 over three 

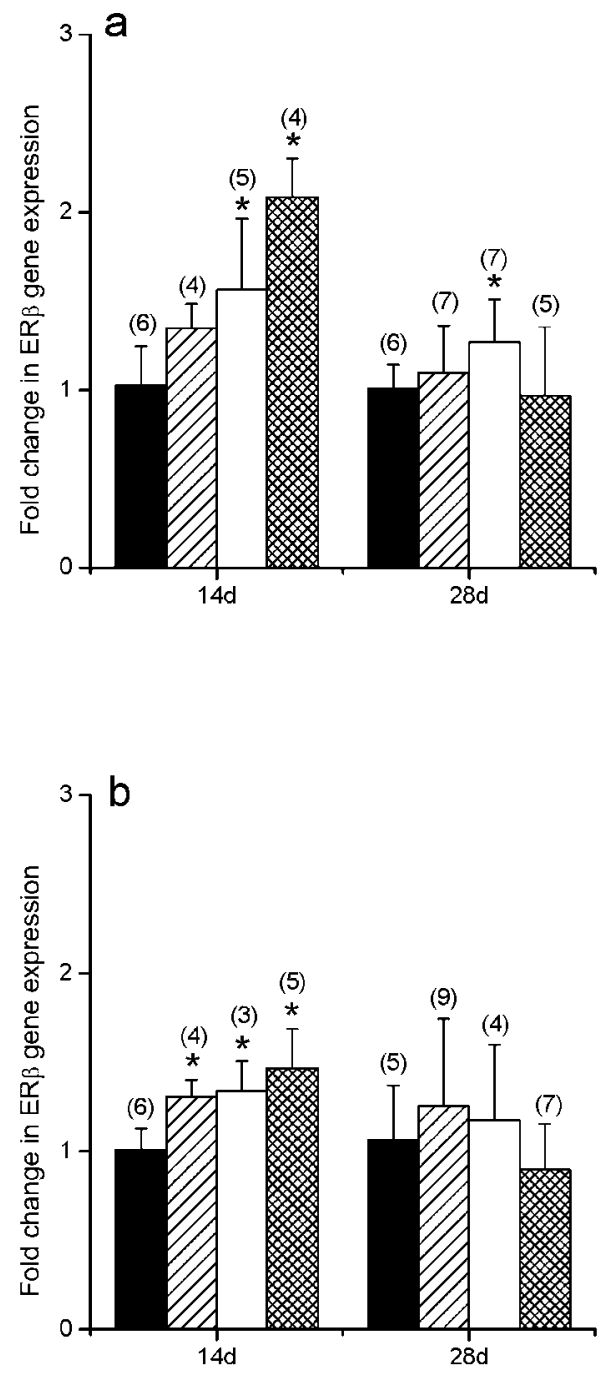

\section{Control; $\mathbb{Z} 3 \mathrm{mg} / \mathrm{L} ; \square 10 \mathrm{mg} / \mathrm{L} ; \otimes 30 \mathrm{mg} / \mathrm{L}$}

Fig. 5. Real-time quantitative polymerase chain reaction (PCR) analysis of hepatic estrogen receptor $\beta$ (ER $\beta)$ gene in rare minnows. Expression levels in males (a) and females (b) exposed to perfluorooctanoic acid for 14 and $28 \mathrm{~d}$ were quantified using real-time quantitative PCR. Bars represent the fold change of exposed versus control. For individual total liver RNA, four to nine fish were used, and $\beta$ actin was used for normalization. Measurements were repeated three times; asterisks denote significant differences from the control at $p$ $<0.05$. Error bars indicate standard deviation of the samples. The numbers of fish are given in parentheses.

years exhibited slightly fibrotic seminiferous tubules that lacked lumena [33].

Ovarian changes in females exposed to estrogens have been observed through histological examination in several fish species. For example, oocytes in female fathead minnows exposed to waterborne E2 for $14 \mathrm{~d}$ exhibited degenerative changes [34]. Mature female zebrafish (Danio rerio) exposed to EE2 for 24 $\mathrm{d}$ showed degeneration of vitellogenic-stage oocytes, reduction of yolks in oocytes, and a decrease of the gonadosomatic index [34]. As in this study, the vitellogenic stage oocytes in female rare minnows exposed to PFOA for $28 \mathrm{~d}$ degenerated. It is unknown still whether the degeneration of vitellogenic-stage oocytes and the barrier of female reproduction in this study
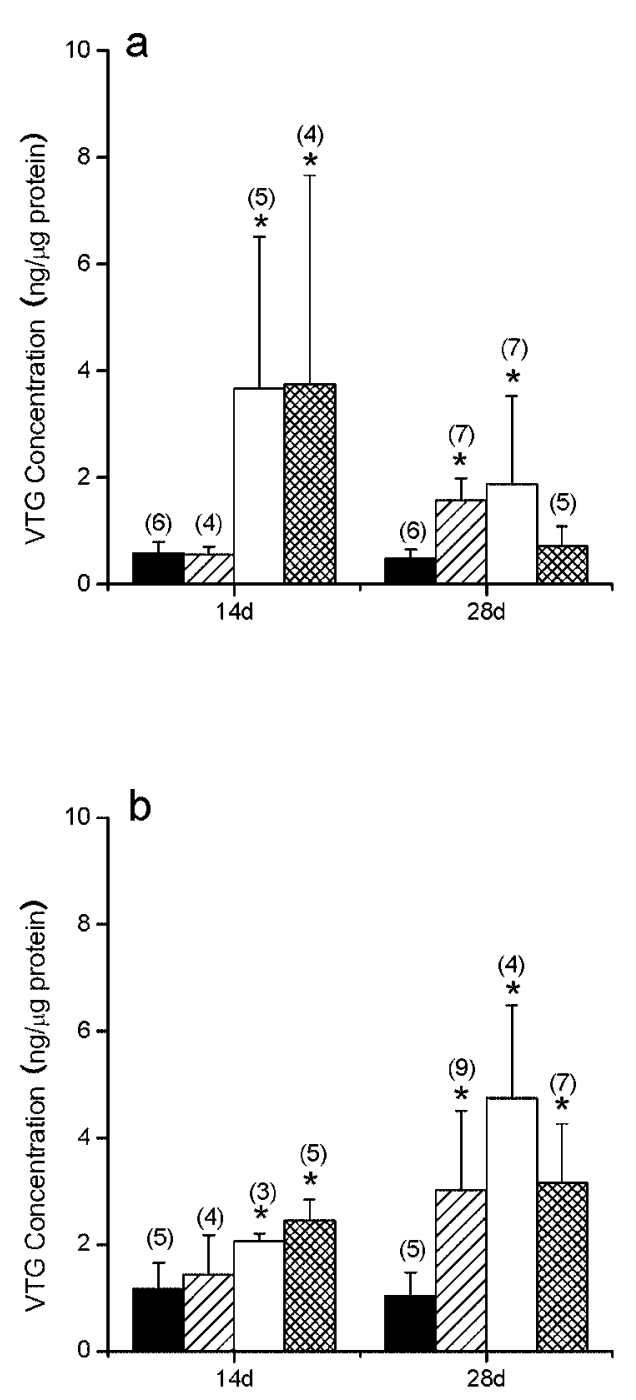

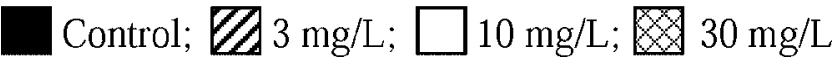

Fig. 6. Hepatic vitellogenin (VTG) concentrations in mature rare minnows exposed to perfluorooctanoic acid. Values are means \pm standard deviation. The asterisks denote significant difference from the control at $p<0.05$. The error bars indicate standard deviation of the mean. The numbers of fish are given in parentheses. (a) Males and (b) females.

are the effect of estrogens; at the least it was endpoint due to exposure to PFOA. The data from this study delivered a clear message that we should pay extra attention to the effect of environmental disruptors on female reproduction in future study.

Several studies show that estrogenic compounds can induce hepatic VTG synthesis in male fish. Zha et al. [29] reported that plasma VTG in male rare minnows exposed to different concentrations of EE2 and NP were significantly higher than in control males. A similar result also was obtained after male rare minnows were exposed to diethylstilbestrol for $118 \mathrm{~d}$; the level of VTG in whole body homogenates increased significantly, almost the same as that of mature females [24]. Using VTG protein analysis, Kang et al. [35] reported that hepatic VTG levels were significantly elevated in male medaka exposed to $50.9 \mu \mathrm{g} / \mathrm{L} \mathrm{NP}$ and 3,120 $\mu \mathrm{g} / \mathrm{L}$ bisphenol-A for $21 \mathrm{~d}$. 
However, VTG concentrations in males did not always increase with an increase of exposure concentrations. For example, in the present study, there was a subsequent decrease in hepatic VTG concentrations in male rare minnows exposed to 10 and $30 \mathrm{mg} / \mathrm{L}$ PFOA between 14- and 28-d exposures. This may be due to liver damage at higher exposure concentrations of PFOA, or there may be a limit on the level of hepatic VTG concentration that can be attained. In both male and female zebrafish exposed to higher EE2 concentrations with longer treatment times, plasma VTG concentrations also showed a decrease [32].

To date, studies on endocrine-disrupting activities of fluorinated compounds are few. Lau et al. [12] highlighted that fluorinated compounds caused disturbances of the thyroid gland. Maras et al. [36] found that 6:2 fluorotelomer alcohols $1 \mathrm{H}, 1 \mathrm{H}, 2 \mathrm{H}, 2 \mathrm{H}$,-perfluorooctan-1-ol $(\mathrm{FTOH})$ and $1 \mathrm{H}, 1 \mathrm{H}, 2 \mathrm{H}$, 2H,-perfluoro-decan-1-ol (8:2 FTOH) behaved like xenoestrogens in vitro, but PFOA seemed not to possess estrogen-like properties. In vitro assays, however, may not perfectly reflect the true in vivo response of fish to that compound. Oakes et al. [37] reported that VTG in immature rainbow trout was elevated in both sexes following exposure for $12 \mathrm{~d}$ to 3 $\mathrm{mg} / \mathrm{L}$ perfluorooctanesulfonate, a chemical structurally similar to PFOA, whereas no significant changes in plasma VTG concentrations were observed in adults following perfluorooctanesulfonate exposure.

Estrogen receptors are vital for not only the endogenous estrogen but also the xenoestrogen to induce the expression of VTG in animal livers [38]. Although the structure of PFOA is not similar to those of estrogens, it may not deny the possibility of PFOA binding to the ER and eliciting the downstream response. In the present study, both male and female rare minnows in all the exposed groups after the 14-d exposure displayed the significant increase in hepatic VTG synthesis as compared to the control. The result suggested that the ER $\beta$ might play a role in mediating the disruption of estrogen activity by PFOA. However, in the groups of the 28 -d exposure, the mRNA level of ER $\beta$ almost recovered to the same levels as in the control in both males and females, except for the males in the group exposed to $10 \mathrm{mg} / \mathrm{L}$ PFOA. This indicated that the alterations of ER $\beta$ mRNA level were distinct for different duration of exposure. Several studies have shown that endocrine disruptors (including xenoestrogen) affected ER $\beta$ expression. Soverchia et al. [39] showed that the changes of plasma VTG and E2 in juvenile goldfish (Carassius auratus) exposed to E2 and 4-NP were in agreement with the increasing transcriptional rate of ER $\beta-1$ mRNA in the livers. Tributyltin exposure can produce concentration-specific increase in ER $\beta$ in juvenile Atlantic salmon (Salmo salar) [40].

Perfluorooctanoic acid may change the ratio of endogenous E2:testosterone $(\mathrm{T})$, creating an estrogenic milieu and having profound biochemical, physiological, reproductive, and developmental consequences. In mammals, PFOA exposure has been shown to induce aromatase cytochrome P450 activity, which catalyses the conversion of $\mathrm{T}$ to $\mathrm{E} 2$, with the consequent reduction of $\mathrm{T}$ concomitant with an increase in E2 [41]. In teleosts, little evidences of increased aromatase have been seen in fish exposed to PFOA. Circulating $\mathrm{T}$ was reduced significantly in both male and female fathead minnows at PFOA concentrations above $1.0 \mathrm{mg} / \mathrm{L}$, although circulating E2 was altered with PFOA exposure, but with significant reduction at concentrations only above $30 \mathrm{mg} / \mathrm{L}$ in females [13]. Either of these mechanisms could lead to enhanced production of VTG and the responses shown in this study. In future studies, the levels of VTG, T, and E2 in plasma or gonads of rare minnows can be measured to better understand these steroid metabolisms after exposure to PFOA.

\section{CONCLUSION}

Perfluorooctanoic acid has been demonstrated, for the first time, to significantly increase hepatic VTG concentration and induce testis-ova gonads in mature male rare minnows. However, only relatively high exposure concentrations of PFOA (10 and $30 \mathrm{mg} / \mathrm{L}$ for $28 \mathrm{~d}$ ) induced testes-ova. This laboratory study suggests that PFOA can disrupt the activity of estrogen by inducing hepatic estrogen-responsive genes in males, although the mechanism of development of testes-ova in rare minnows by PFOA exposure is unknown. Further research in this area would be desirable, with particular attention given to the status of enzymes involved in steroid metabolism.

Acknowledgement-This research was supported by the National Natural Science Foundation of China (20677060), the Innovation Program of the Chinese Academy of Sciences (KSCX2-SW-128), and National Basic Research Program of China (2003CB415005). The authors would like to thank Y. Xu of the Institute of Hydrobiology, Chinese Academy of Sciences, who generously provided the antibody and gave suggestion about the enzyme-linked immunosorbent assay experiment.

\section{REFERENCES}

1. Giesy JP, Kansan K. 2001. Global distribution of perfluorooctane sulfonate in wildlife. Environ Sci Technol 35:1339-1342.

2. Prevedouros K, Cousins IT, Buck RC, Korzeniowski SH. 2006. Sources, fate, and transport of perfluorocarboxylates. Environ Sci Technol 40:32-44.

3. Martin JW, Smithwick MM, Braun BM, Hoekstra PF, Muir DC, Mabry SA. 2004. Identification of long-chain perfluorinated acids in biota from the Canadian Arctic. Environ Sci Technol 38:373380.

4. Smithwick M, Muir DC, Mabury SA, Solomon KR, Martin JW, Sonne C, Born EW, Letcher RJ, Dietz R. 2005. Perfluoroalkyl contaminants in liver tissue from East Greenland polar bears $(\mathrm{Ur}$ dus Maritimes). Environ Toxicol Chem 24:981-986.

5. Yeung LW, So MK, Jiang G, Taniyasu S, Yamashita N, Song M, Wu Y, Li J, Giesy JP, Guruge KS, Lam PK. 2006. Perfluorooctanesulfonate and related fluorochemicals in human blood samples from China. Environ Sci Technol 40:715-720.

6. Dai JY, Li M, Jin YH, Saito N, Xu MQ, Wei FW. 2006. Perfluorooctanesulfonate and perfluorooctanoate in Red Panda and Giant Panda from China. Environ Sci Technol 40:5647-5652.

7. Hekster FM, Laane RW, de Voogt P. 2003. Environmental and toxicity effects of perfluoroalkylated substances. Rev Environ Contam Toxicol 179:99-121.

8. Kennedy GL Jr, Butenhoff JL, Olsen GW, O'Connor JC, Seacat AM, Perkins RG, Biegel LB, Murphy SR, Farrar DG. 2004. The toxicology of perfluorooctanoate. Crit Rev Toxicol 34:351-384.

9. O'Brien TM, Wallace KB. 2004. Mitochondrial permeability transition as the critical target of $\mathrm{N}$-acetyl perfluorooctane sulfonamide toxicity in vitro. Toxicol Sci 82:333-340.

10. Seacat AM, Thomford PJ, Hansen KJ, Olsen GW, Case MT, Butenhoff JL. 2002. Subchronic toxicity studies on perfluorooctanesulfonate potassium salt in cynomolgus monkeys. Toxicol Sci 68: 249-264.

11. Hanson ML, Small J, Sibley PK, Boudreau TM, Brain RA, Mabury SA, Solomon KR. 2004. Microcosm evaluation of the fate, toxicity, and risk to aquatic macrophytes from perfluorooctanoic acid (PFOA). Arch Environ Contam Toxicol 49:307-316.

12. Lau C, Butenhoff JL, Rogers JM. 2004. The developmental toxicity pf perfluoroalkyl acids and their derivatives. Toxicol Appl Pharmacol 198:231-241.

13. Oakes KD, Sibley PK, Martin JW, Solomon KR, Mabury SA, Kraak GLVD. 2004. Impact of perfluorooctanoic acid on fathead minnow (Pimephales promelas) fatty acyl-CoA oxidase activity, circulating steroids, and reproduction in outdoor microcosms. Environ Toxicol Chem 23:1912-1919. 
14. Ankley GT, Kuehl DW, Kahl MD, Jensen KM, Linnum A, Leino RL, Villeneuve DA. 2005. Reproductive and developmental toxicity and bioconcentration of perfluorooctanesulfonate in a partial life-cycle test with the fathead minnow (Pimephales promelas). Environ Toxicol Chem 24:2316-2324.

15. Kling CM, Bowers JL, Kulakosky PC, Kamboj KK, Swanson HI. 1999. The aryl hydrocarbon receptor (AHR)/AHR nuclear translocator (ARNT) heterodimer interacts with naturally occurring estrogen response elements. Mol Cell Endocrinol 157:105-119.

16. Gillesby BE, Zacharewski TR. 1998. Exoestrogens: Mechanism of action and strategies for identification and assessment. Environ Toxicol Chem 17:3-14.

17. Mommsen TP, Walsh PJ. 1988. Vitellogenesis and oocyte assembly. Fish Physiol 11A:347-406.

18. Sumpter JP, Jobling S. 1995. Vitellogenesis as a biomarker of estrogenic contamination of the aquatic environment. Environ Health Perspect 103(Suppl 7):173-178.

19. Zhou QF, Jiang GB, Yan JY. 2002. Effects of sublethal levels of tributyltin chloride in a new toxicity test organism: The Chinese rare minnow (Gobiocypris rarus). Arch Environ Contam Toxicol 42:332-337.

20. Zhong XP, Xu Y, Liang Y, Liao T, Wang JW. 2005. The Chinese rare minnow (Gobiocypris rarus) as an in vivo model for endocrine disruption in freshwater teleosts: A full life-cycle test with diethylstilbestrol. Aquat Toxicol 71:85-95.

21. Grier HJ. 1981. Cellular organization of the testis and spermatogenesis in fishes. Am Zool 21:345-357.

22. Livak KJ, Schmittgen TD. 2001. Analysis of relative gene expression data using real-time quantitative PCR and the 2 (-Delta Delta C [T]) Method. Methods 25:402-408.

23. Zhong XP, Xu Y, Liang Y, Liao T, Wang JW. 2004. Vitellogenin in rare minnow (Gobiocypris rarus): Identification and induction by waterborne diethylstilbestrol. Comp Biochem Physiol C Toxicol Pharmacol 137:291-298.

24. Liao T, Jin SW, Yang FX, Hui Y, Xu Y. 2006. An enzyme-linked immunosorbent assay for rare minnow (Gobiocypris rarus) vitellogenin and comparison of vitellogenin responses in rare minnow and zebrafish (Danio rerio). Sci Total Environ 364:284294.

25. Bradford MM. 1976. A rapid and sensitive method for the quantitation of microgram quantities of protein utilizing the principle of protein-dye binding. Anal Biochem 72:248-252.

26. Nakayama S, Harada K, Inoue K, Sasaki K, Seery B, Saito N, Koizumi A. 2005. Distributions of perfluorooctanoic acid (PFOA) and perfluorooctane sulfonate (PFOS) in Japan and their toxicities. Environ Sci 12:293-313.

27. Skutlarek D, Exner M, Farber H. 2006. Perfluorinated surfactants in surface and drinking waters. Environ Sci Pollut Res Int 13: 299-307.

28. Moody CA, Martin JW, Kwan WC, Muir DCG, Mabury SA. 2002. Monitoring perfluorinated surfactants in biota and surface water samples following an accidental release of fire-fighting foam into Etobicoke Creek. Environ Sci Technol 36:545-551.

29. Zha JM, Wang ZJ, Wang N, Ingersoll C. 2007. Histological al- ternation and vitellogenin induction in adult rare minnow ( $G o$ biocypris rarus) after exposure to ethynylestradiol and nonylphenol. Chemosphere 66:488-495.

30. Gray MA, Metcalfe CD. 1997. Induction of testis-ova in Japanese medaka (Oryzias latipes) exposed to p-nonylphenol. Environ Toxicol Chem 16:1082-1086.

31. Länge R, Hutchinson TH, Croudace CP, Siegmund F, Schweinfurth H, Hampe P, Panter GH, Sumpter JP. 2001. Effects of the synthetic estrogen $17 \alpha$-ethinylestradiol on the life-cycle of the fathead minnow (Pinephales promelas). Environ Toxicol Chem 20:1216-1227.

32. Miles-Richardson SR, Kramer VJ, Fitzgerald SD, Render JA, Yamini B, Barbee SJ, Giesy JP. 1999. Effects of waterborne exposure of $17 \beta$-estradiol on secondary sex characteristics and gonads of fathead minnows (Pimephales promelas). Aquat Toxicol 47:129-145.

33. Palace VP, Wautier KG, Evans RE, Blanchfield PJ, Mills KH, Chalanchuk SM, Godard D, McMaster ME, Tetreault GR, Peters LE, Vandenbyllaardt L, Kidd KA. 2006. Biochemical and histopathological effects in pearl dace (Margariscus margarita) chronically exposed to a synthetic estrogen in a whole lake experiment. Environ Toxicol Chem 25:1114-1125.

34. Van den Belt K, Wester PW, Van der Ven LTM, Verheyen R, Witters H. 2002. Effects of ethynylestradiol on the reproductive physiology in zebrafish (Danio rerio): Time dependency and reversibility. Environ Toxicol Chem 21:767-775.

35. Kang IJ, Yokota H, Oshima Y, Tsuruda Y, Hano T, Maeda M, Imada N, Tadokoro H, Honjo T. 2003. Effects of 4-nonylphenol on reproduction of Japanese medaka, Oryzias latipes. Environ Toxicol Chem 22:2438-2445.

36. Maras M, Vanparys C, Muylle F, Robbens J, Berger U, Barber J, Blust R, Coen WD. 2006. Estrogen-like properties of fluorotelomer alcohols as revealed by MCF-7 breast cancer cell proliferation. Environ Health Perspect 114:100-105.

37. Oakes KD, Sibley PK, Martin JW, MacLean DD, Solomon KR, Mabury SA, Van Der Kraak GJ. 2005. Short-term exposures of fish to perfluorooctane sulfonate: Acute effects on fatty acyl-coa oxidase activity, oxidative stress, and circulating sex steroids. Environ Toxicol Chem 24:1172-1181.

38. Tyler CR, Jobling S, Sumpter JP. 1998. Endocrine disruption in wildlife: A critical review of the evidence. Crit Rev Toxicol 28: 319-361.

39. Soverchia L, Ruggeri B, Palermo F, Mosconi G, Cardinaletti G, Scortichini G. 2005. Modulation of vitellogenin synthesis through estrogen receptor beta-1 in goldfish (Carassius auratus) juveniles exposed to 17-beta estradiol and nonylphenol. Toxicol Appl Pharmacol 209:236-243.

40. Mortensen AS, Arukwe A. 2007. Modulation of xenobiotic biotransformation system and hormonal responses in Atlantic salmon (Salmo salar) after exposure to tributyltin (TBT). Comp Biochem Physiol C Toxicol Pharmacol 145:431-441.

41. Biegel LB, Hurtt ME, Frame SR, O’Connor JC, Cook JC. 2001. Mechanisms of extrahepatic tumor induction by peroxisome proliferators in male CD rats. Toxicol Sci 60:44-55. 